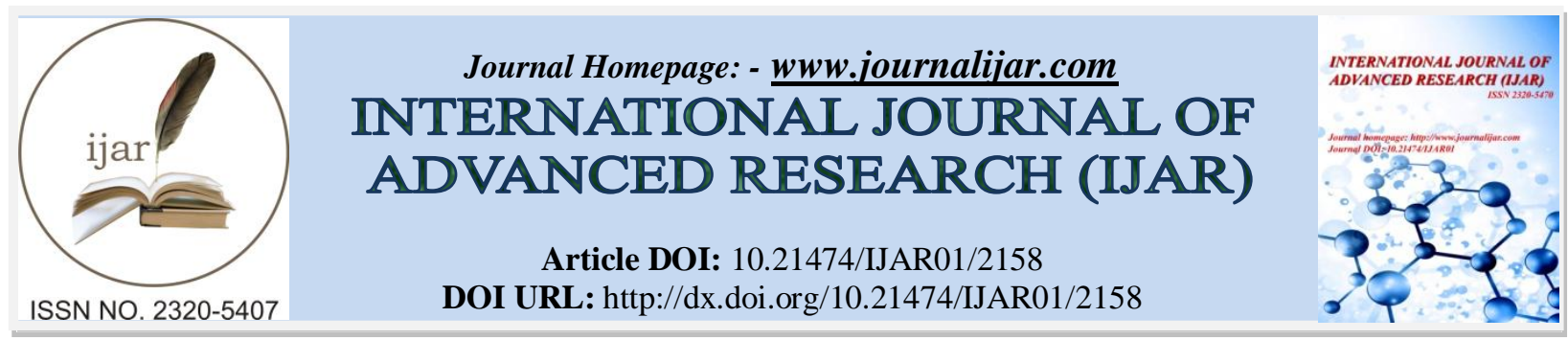

RESEARCH ARTICLE

\title{
EFFECT OF GELATIN AND PAPAYA EXTRACT COMBINATIONS ON MICROBIAL AND RANCIDITY DEVELOPMENT OF FRESH BROILER CHICKEN BREAST
}

\section{Abd Elgadir.}

Food Science \& Human Nutrition Department, College of Agriculture and Veterinary Medicine, Qassim University, Saudi Arabia.

\section{Manuscript Info}

Manuscript History

Received: 26 September 2016

Final Accepted: 29 October 2016

Published: November 2016

Key words:-

Gelatin, dipping procedure, chicken

breast, papaya extract

\section{Abstract}

Fresh breast chicken cuts were prepared and dipped individually in solutions of gelatin combined with papaya extract in a ratio of 1:1, 2: 1 and 1:2, respectively. The control and treated samples were then dripped dried and packaged individually aerobically in ethylene vinyl acetate bags (EVA) and stored at refrigeration temperature of $4^{\circ} \mathrm{C}$ for 15 days. $\mathrm{pH}$, microbial (Total plate count, TPC), colour and rancidity (Thiobarbituric acid, TBA) were investigated on first day and every 5 days intervals. The study revealed that the combination treatment gave better results in all parameters measured compared to the control. For single treatment it was observed that gelatin in the mentioned concentration was more effective in slowing both microbial growth and rancidity development. However, in combination treatments, gelatin combined with papaya extract in the ratio of 2: 1 had the best result in this regard. In conclusion, for better avoidance of rapid microbial growth and rancidity development the combination of gelatin and papaya extract in the ratio of 2: 1 is highly recommended.

Copy Right, IJAR, 2016,. All rights reserved.

\section{Introduction:-}

Fresh meat is well recognized as one of the most perishable foods. This is because of rapid microbial growth to unacceptable levels which significantly contributing to meat spoilage (Gram et al., 2002 and Fung, 2010) and then the meat becomes unsuitable for human consumption.

Poultry carcasses and cuts are usually contaminated with many types of microorganisms such as Salmonella and Campylobacter (Simmons et al., 2003), Clostridium perfringens (Kessel et al., 2001), Escherichia coli 0157 (Kessel et al. (2001) and Listeria monocytogenes (Gonzalez-Fandos, 2014). When poultry meat is aerobically stored under chill conditions, spoilage microorganisms such as Pseudomonas spp., are normally present (Zhang et a, 2012). The spoilage of refrigerated fresh chicken is partially caused by microbial growth such as Pseudomonas species bacteria which are responsible for the discoloration, off flavours, off odours, gas and slime production (Petrová et al., 2013).

Earlier, papaya extract gave positive effect against bacterial infections (Wimalawansa, 1981). An in vitro studies conducted on extracts from skin, flesh, and seeds of both ripe and unripe papaya gave antibacterial activities against various microorganisms including Staphylococcus aureus, Bacillus subtilis, Bacillus cereus, Escherichia coli, Enterobacter cloacae, Proteus vulgaris, Klebsiella pneumoniae, Salmonella typhi, Pseudomonas aeruginosa and 
Shigella Flexner (Yismaw, 2008). Gelatin is considered as one of the most popular biopolymers. It is tasteless and colourless solid substance derived from the fibrous protein collagen. It is widely used in meat applications alone or with other medicinal plants because of its unique functional, technological and antimicrobial properties (Tiwari, 2009 and Jayathilakan, 2012). This study was carried out to investigate the effects of gelatin and gelatin combined with papya on microbial and rancidity development of fresh chicken meat.

\section{Materials and methods:-}

Preparation of meat samples:-

Recently slaughtered broiler chicken breasts were purchased from local market (Selangor, Malaysia). The meat cuts were prepared by slicing the chicken breasts parallel to the muscles fibres direction to pieces measuring 1 × 10 × 5 $\mathrm{cm}$ (thickness $\mathrm{x}$ length $\mathrm{x}$ width) and surface area of approximately $50 \mathrm{~cm}^{2}$ and weighing about $80 \mathrm{~g}$ using filleting knife.

\section{Preparation of papaya extract:-}

The leaves of papaya were collected from papaya farm, Asia Fruits, Selangor, Malaysia. The leaves were transported to extraction laboratory, Universiti Technologi MARA (UiTM). The leaves were then washed with tab water to remove strange materials and spread on clean table and left to dry overnight at room temperature. The semi dry leaves were placed next day in an oven set at $45^{\circ} \mathrm{C}$ and left for one week to fully dry. The dry leaves were broken by hands into small pieces and placed in a Waring blender set at high speed for $20 \mathrm{~min}$. and a fine powder of the leaves were obtained. According to modified method of Skandamis (2002) aqueous extraction was conducted using methanol and water in a ratio of 20: 80, respectively. $20 \mathrm{~g}$ of the dry blended leaves were placed in $1000 \mathrm{~mL}$ flask and the mixture of methanol in water was added in the ratio of 1:20 (blended leaves: mixture of methanol in water, respectively). The flask was covered with aluminum foil and left till the next day. The mixture was filtered through filter paper no.1 using a funnel. The filtrate was collected and rotor vaporized to remove the water. The extract was then freeze - dried using freeze dryer model (Scanvac Coolsafe, RZ 2.5, Germany) and the extract in form of powder of was obtained. The powder of the extract was then placed in a clean dry bottle using paraffin lamination till use.

\section{Preparation of treatment solutions:-}

50 gram of either gelatin (gelatin type B from bovine skin which was purchased from Sigma Co., Malaysia) or papaya extract individually were placed in a $1000 \mathrm{ml}$ beaker. Deionized water was added and the beaker was put in hot water bath to enhance melting. The contents were mixed thoroughly with glass rod individually or together using. The solution then was left to cool down at room temperature. For preparation of combination of gelatin and papaya in a ratio of $1: 1$ and concentration of $5 \%, 25$ gram from each were taken and the same procedure was followed.

\section{Samples treatment:-}

The meat samples were dipped in the prepared solutions individually for $5 \mathrm{~min}$ and after that left to drip dry for 15 min. The control sample was dipped in deionized water. Triplicate of each treatment was conducted. The treated samples were then stored at refrigeration temperature for 15 days. Measurements were taken in the first day and every 5 days interval.

\section{pH measurement:-}

10 grams of the sample were obtained and homogenized with $90 \mathrm{ml}$ of deionized water (in the ratio of 1:9), using laboratory blender (Waring products Division Torrington, CT, USA.) for $1 \mathrm{~min}$ at low speed. Digital $\mathrm{pH}$ meter (Tolledo $420 \mathrm{pH}$ meter, Mettler- Instrument, Germany) was used after standardizing it with two-buffer solutions; one in $\mathrm{pH}$ 7.0, and the other in $\mathrm{pH}$ 4.0. The $\mathrm{pH}$ values of the samples were measured on first day (day 0 ) and every 5 days during storage period at $4^{\circ} \mathrm{C}$. The $\mathrm{pH}$ of readings were obtained in the slurry of the samples with the direct insertion of the $\mathrm{pH}$ probe electrode of the $\mathrm{pH}$ meter. Triplicates measurement were taken from each sample.

\section{Total plate count assessment:-}

Total Plates Counts (TPC) of the samples were determined according to the method of Pizato et al. (2015). $10 \pm 0.1$ grams of were removed from each package using a sterile knife and weight is taken using sensitive balance (4 decimal digits).The sample were then aseptically transferred to a steriled stomacher bag containing $90 \mathrm{~mL}$ of peptone water. The samples were put in a stomacher blender 400 (UAC, London, Britain) and homogenized individually for $2 \mathrm{~min}$. Serial dilutions of $10^{-2}, 10^{-3}, 10^{-4}, 10^{-5}$ and $10^{-6}$ were then prepared. $0.1 \mathrm{~mL}$ of each above 
dilution was spread on the plate count agar and the plates were incubated at $37^{\circ} \mathrm{C}$ for $48 \mathrm{hr}$. TPC were obtained from plates bearing $30-300$ colonies in all samples. Triplicate measurements were taken and reported as the $\log _{10}$ of the numbers of colony forming units.

\section{Thiobarbituric acid value measurement:-}

2-Thiobarbituric acid value was determined using distillation method described by Egan et al. (1981). Thiobarbituric acid (TBA) solution was prepared using acetic acid glacial 90\%. $0.2883 \mathrm{~g}$ of TBA powder was accurately taken and dissolved in $100 \mathrm{~mL}$ acetic acid solution (w/v) was prepared by dissolving TBA powder (w/v). $10 \mathrm{~g}$ of the meat were macerated with $50 \mathrm{~mL}$ of distilled water for $2 \mathrm{~min}$. and the mixture was then washed into a distillation flask with $47.5 \mathrm{~mL}$ of distilled water. $2.5 \mathrm{~mL}$ of $4 \mathrm{~N}$ hydrochloric acid were added to the mixture, together with an antifoaming agent A (Sigma), and a few glass beads were added. The mixture was placed in a round bottom flask (250 $\mathrm{mL}$ ) and boiled for $10 \mathrm{~min}$. About $50 \mathrm{~mL}$ of the distillate was collected and $5 \mathrm{~mL}$ of the distillate obtained were pipetted into a glass-stoppered tube. $5 \mathrm{~mL}$ of TBA solution were added to the mixture. The tube was stoppered, shaken well and heated in a boiling water bath for $35 \mathrm{~min}$. A blank tube was similarly prepared using $5 \mathrm{~mL}$ of water and $5 \mathrm{~mL}$ of the reagent without meat sample. The tubes were then cooled in water for $10 \mathrm{~min}$. A spectrophotometer model (82-2118-00, Cambridge, England) was used for the measurement. The absorbance value of the colour (D) was measured through a $10 \mathrm{~mm}$ glass cell against blank sample at light weave length of $538 \mathrm{~nm}$. The TBA value was then calculated as milligrams of as malonaldehyde (MA) per kilogram of sample which is equal to $7.8 \mathrm{x}$ D. Triplicates of measurements were recorded.

\section{Statistical Analysis:-}

The data obtained were analysed for two way analysis of variance (ANOVA) using Minitab Statistical Software (Minitab Inc., PA, USA) package 16. The results are expressed as mean \pm S.D.

\section{Results and Discussion:-}

The results of this study during storage period are present in Table 1, Figure 1 Table 2. The pH values of the samples ranged from 5.0 to 7.5. Comparing to the control sample, all treatments have shown decreases in the values of the $\mathrm{pH}$. The value dropped from 5.5 to 5.2, 5.3, 5.1, 5.1 and 5.0 in the sample treated with PS alone, GS alone, combination of PS:GS in (1:1), PS:GS (1:2) and PS:GS (2:1), respectively. The lowest pH value was observed in the sample treated with the combination of PS:GS in the concentration of 2:1. During storage period the $\mathrm{pH}$ values of all samples increased gradually till reached the maximum value of 7.5 in control sample. At the end of the storage period the highest $\mathrm{pH}$ value was observed followed by samples treated with GS, PS: GS (1:2), PS: GS (1:1), PS and PS: GS (2:1), respectively. Yang et al. (2014) reported that in normal pH meat only few microorganisms such as C. frigidicarnis, C. estertheticum and C.tagluense could be possibly grow substantially. Mountfort et al., (1997) and Spring et al. (2003) reported that the minimum $\mathrm{pH}$ values for growth of such microorganisms was above 5.5. Low $\mathrm{pH}$ value $(<5.0)$ would seem to be an indicator of some spoilage microorganisms such as C. algoriphilum, C. frigidicarnis and C. algidixylanolyticum (Broda et al., 1999, Broda et al., 2000 and Shcherbakova et al., 2005). Even so, low pH would seem to play a part in restricting the growth of most of the species on normal $\mathrm{pH}$ meat, because most grew well on meat of intermediate $\mathrm{pH}$ and all grew well on meat of high $\mathrm{pH}$ value.

Table 1:- $\mathrm{pH}$ value of the samples during storage at $4^{\circ} \mathrm{C}$ for 15 days.

\begin{tabular}{|c|c|c|c|c|c|c|c|}
\hline Days of storage & Control & PS & GS & PS:GS (1:1) & PS:GS (1:2) & PS:GS (2:1) \\
\hline \multicolumn{7}{|c|}{ pH vales } \\
\hline 0 & $5.5 \pm 0.2$ & $5.2 \pm 0.1$ & $5.4 \pm 0.1$ & $5.1 \pm 0.2$ & $5.1 \pm 0.1$ & $5.0 \pm 0.2$ \\
\hline 5 & $5.8 \pm 0.3$ & $5.4 \pm 0.2$ & $5.6 \pm 0.2$ & $5.3 \pm 0.2$ & $5.4 \pm 0.3$ & $5.2 \pm 0.2$ \\
\hline 10 & $6.6 \pm 0.2$ & $5.8 \pm 0.2$ & $6.2 \pm 0.4$ & $5.5 \pm 0.4$ & $5.7 \pm 0.4$ & $5.5 \pm 0.1$ \\
\hline 15 & $7.5 \pm 0.1$ & $6.0 \pm 0.3$ & $6.6 \pm 0.3$ & $5.9 \pm 0.2$ & $6.1 \pm 0.3$ & $5.8 \pm 0.3$ \\
\hline
\end{tabular}

Note:

PS: Gelatin solution

GS: Papaya solution

The initial TPC of control sample was $3.5 \log _{10}$ per $g$ and it was decreased to between 3.1 to $3.5 \log _{10}$ per $\mathrm{g}$ in the treated samples. After treatments all samples showed decreases in TPC values. They were in the order control > PS: GS (1:2) > GS > PS > PS: GS (2:1). At the end of the storage time highest microbial growth was observed in 
control sample. The value jumped from 3.5 to 6.5 while on the other hand the sample treated with PS: GS (2:1) gave the lowest microbial growth. Shaikh et al. (2003) reported that meat samples developed off-odor and discoloration with TPC $>10^{6} \mathrm{cfu} / \mathrm{g}$. Also Earlier, It was reported that at $6-7 \log _{10} \mathrm{cfu} / \mathrm{g}$, meat reached spoilage and it became unsalable (Dainty and Mackey, 1992). In this study it was observed that the TPC at which meat could be considered as spoiled when the microbial reaches $10^{6} \mathrm{cfu} / \mathrm{g}$ was not reached on last day of storage (day 15). The best treatment that caused good inhibition in microbial growth at the end of the storage period was the sample treated with PS: GS $(2: 1)$.

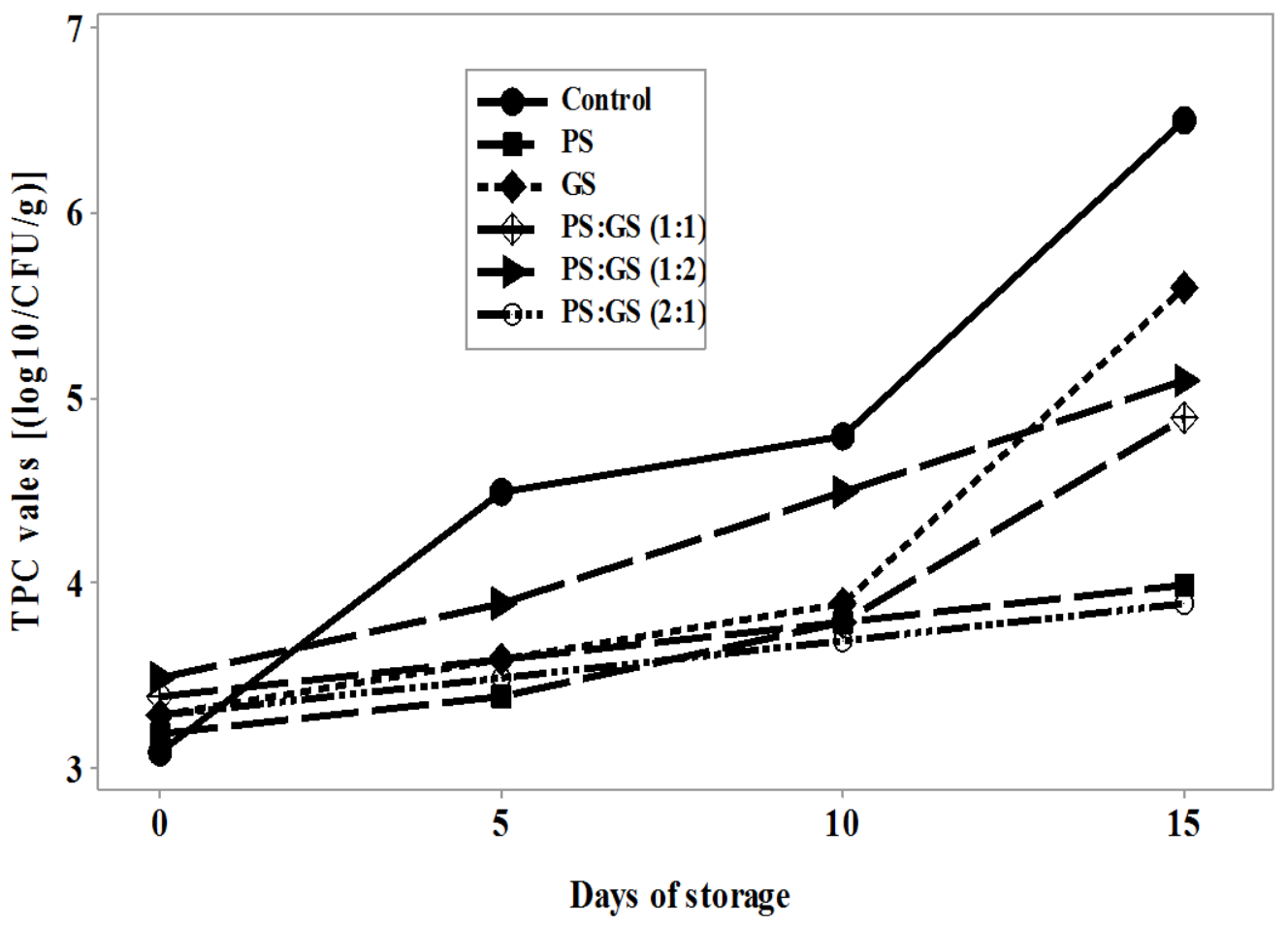

Figure 1: Scatte rplot of TPC values of the samples during storage at $40 \mathrm{C}$ for 15 days.

Lipid oxidation showed the same trend similar to $\mathrm{pH}$ and microbial growth. TBA increase significantly $(\mathrm{p}<0.05)$ in control sample from $0.35 \mathrm{mg} \mathrm{MDA} / \mathrm{kg}$ reaching a value of $0.68 \mathrm{mg} \mathrm{MDA} / \mathrm{kg}$. Earlier, Boles and Parrish (1990) have reported that a warmed-over flavor of meat could be perceived in meat products when TBA values reached above $1.0 \mathrm{mg} \mathrm{MDA} / \mathrm{kg}$. In another studies it was reported that a rancid flavor is initially detected in meat products with TBA value of 2.0 (Gray and Pearson (1987). The best treatment that controlled lipid oxidation development in this study was the combination of gelatin and papaya extract in the ratio of 2: 1 .

Table 2:- TBA value of the samples during storage at $4^{\circ} \mathrm{C}$ for 15 days.

\begin{tabular}{|c|c|c|c|c|c|c|}
\hline $\begin{array}{c}\text { Days of } \\
\text { storage }\end{array}$ & Control & PS & GS & PS:GS (1:1) & PS:GS (1:2) & $\begin{array}{c}\text { PS:GS } \\
\text { (2:1) }\end{array}$ \\
\hline \multicolumn{7}{|c|}{ TBA vales (mg Malonaldehyde/kg) } \\
\hline 0 & $0.35 \pm 0.1$ & $0.32 \pm 0.1$ & $0.34 \pm 0.1$ & $0.33 \pm 0.2$ & $0.36 \pm 0.1$ & $0.34 \pm 0.2$ \\
\hline 5 & $0.39 \pm 0.3$ & $0.35 \pm 0.2$ & $0.33 \pm 0.2$ & $0.31 \pm 0.2$ & $0.39 \pm 0.3$ & $0.36 \pm 0.2$ \\
\hline 10 & $0.46 \pm 0.2$ & $0.38 \pm 0.2$ & $0.42 \pm 0.2$ & $0.35 \pm 0.4$ & $0.47 \pm 0.4$ & $0.38 \pm 0.1$ \\
\hline 15 & $0.68 \pm 0.1$ & $0.45 \pm 0.3$ & $0.46 \pm 0.1$ & $0.43 \pm 0.2$ & $0.51 \pm 0.3$ & $0.41 \pm 0.2$ \\
\hline
\end{tabular}

Note:

PS: Gelatin solution

GS: Papaya solution 


\section{Conclusion:-}

In conclusion, it was found that all treatments caused great delaying in both microbial and rancidity development of chicken breast. The treatment in the ratio of 2:1 was found to be more effective in this regard. It is highly recommended to treat fresh chicken meat with the latter combination for better results. More researches could be needed to investigate additional details such as the relationship between active materials in papya and specific types of microorganisms.

\section{Acknowledgments:-}

The author would like to deeply thank Asia Fruits Sdn. Bhd. Located in Negri Simbilan, Selangor, Malaysia. For their assistance in collecting fresh papaya leaves from their field.

\section{References:-}

1. Boles, J.A. and Parrish, J.R. (1990). Sensory and chemical characteristics of precooked microwave reheatable pork roasts. J. Food Sci., 55: 618 - 620.

2. Broda, D.M., Lawson, P.A., Bell, R.G. and Musgrave, D.R., 1999. Clostridium frigidicarnis sp. nov., a psychrotolerant bacterium associated with 'blown pack' spoilage of vacuum-packed meats. Int. J. Syst. Bacteriol., 49: 1539 - 1550.

3. Broda, D.M., Saul, D.J., Bell, R.G. and Musgrave, D.R., 2000. Clostridium algidixylanolyticum sp. nov., a psychrotolerant, xylan-degrading, spore-forming bacterium. Int. J. Syst. Evol. Microbiol., 50: 623 - 631.

4. Dainty, R. and Mackey, B. 1992. The relationship between the phenotypic properties of bacteria from chillstored meat and spoilage processes. J. Appl. Bacteriol., 73: $103-114$.

5. Egan, H., Kiry, R. and Sawyer, R., (eds.). (1981). TBA measurements. In Person's Chemical Analysis of Foods, p. 537. Churchill - living stone, Edinburgh, U.K.

6. Fung, D.Y. (2010). Microbial hazards in food: food-borne infections and intoxications. In: Toldra, F. (Ed.), Handbook of Meat Processing. Blackwell Publishing, USA, 2010, pp. 481-500.

7. Gonzalez-Fandos, E., and Herrera, B. (2014). Efficacy of Acetic Acid against Listeria monocytogenes Attached to Poultry Skin during Refrigerated Storage. Foods, 3: $527-540$.

8. Gram, L., Ravn, L., Rasch, M., Bruhn, J.B., Christensen, A.B. and Givskov, M. (2002). Food spoilage interactions between food spoilage bacteria. International Journal of Food Microbiology, 78: 79 - 97.

9. Gray, J.I. and Person, A.M. (1987). Rancidity and warmed-over flavor. In Advances in Meat Research (A.M. Pearson and T.R. Dutson, eds.) pp. 221-269. Van Nostrand, New York, NY.

10. Insausti, K., Beriain, J., Purroy, A., Alberti, P., Gorraiz, C. and Alzueta, M. (2000). Shelf life of beef from local Spanish cattle breeds stored under modified atmosphere. J. Meat Sci., 57: 273 - 281.

11. Jayathilakan, K., Sultana, K., Radhakrishna, K., and Bawa, A. S. (2012). Utilization of byproducts and waste materials from meat, poultry and fish processing industries: a review. Journal of Food Science and Technology, 49: $278-293$.

12. Microbiological Quality of Fresh Chicken Breast Meat after Rosemary Essential Oil Treatment and Vacuum Packaging. Animal Science and Biotechnologies, 1: 46.

13. Mountfort, D.O., Rainey, F.A., Burghardt, J., Kaspar, H.F., Stackebrandt, E. (1997). Clostridium vincentii sp. nov., a new obligately anaerobic, saccharolytic, psychrophilic bacterium isolated from low-salinity pond sediment of the McMurdo Ice Shelf, Antarctica. Arch. Microbiol., 167: 54 - 60.

14. Petrová, J., Pavelková, A., Hleba, L., Pochop, J., Rovná, K. and Kačániová, M. (2013). Pizato, S., Cortez-Vega, W. R. and 1Prentice, C. (2015). Quality assessment of cooked chicken breast meat at different storage temperatures. International Food Research Journal, 22: 143-154.

15. Shcherbakova, V.A., Chuvilskaya, N.A., Rivkina, E.M., Pecheritsyna, S.A., Laurinavichius, K.S., Suzina, N.E., Osipov, G.A., Lysenko, A.M., Gilichinsky, D.A. and Akimenko, V.K., 2005. Novel psychrophilic anaerobic spore-forming bacterium from the overcooled water brine in permafrost: description Clostridium algoriphilum sp. nov. Extremophiles, 9: 239 - 246.

16. Skandamis, P., Tsigarida, E., Nychas, G..J.E. (2002). The effect of oregano essential oil on survival/death of Salmonella typhimuriumin meat stored at $5{ }^{\circ} \mathrm{C}$ under aerobic, VP/MAP conditions. Food Microbiology, 19: 97-103.

17. Spring, S., Merkhoffer, B., Weiss, N., Kroppenstedt, R.M., Hippe, H., Stackebrandt, E. (2003). Characterization of novel psychrophilic clostridia from an Antarctic microbial mat: description of Clostridium frigoris sp. nov., Clostridium lacusfryxellense sp. nov., Clostridium bowmanii sp. nov. and Clostridium psychrophilum sp. nov. 
and reclassification of Clostridium laramiense as Clostridium estertheticum subsp. laramiense subsp. nov. Int. J. Syst. Evol. Microbiol., 53: 1019 - 1029.

18. Tiwari, B.K., Valdramidis,V.P., O'Donnell, C.P., Muthukumarappan, K., Bourke, P., Cullen, P.J. (2009). Application of natural antimicrobials for food preservation. J Agric Food Chem., 57: 5987-6000.

19. Wimalawansa, S J. (1981). Papaya in the treatment of chronic infected ulcers. Ceylon Med J., 26: 129 -132.

20. Yang, Y., Youssef, M.K., Colin O. Gill, C.O, Badoni, M and López-Campos, Ó. (2014). Effects of meat pH on growth of 11 species of psychrotolerant clostridia on vacuum packaged beef and blown pack spoilage of the product. Food Microbiology, 39: 13 - 18.

21. Yismaw, G., Tessema, B., Mulu, A., Tiruneh, M. (2008). The in-vitro assessment of antibacterial effect of papaya seed extract against bacterial pathogens isolated from urine, wound and stool. Ethiop Med J., 46: 71-77.

22. Zhang, Q.Q, Han, Y.Q, Cao, J. X., Xu, X.L., Zhou, C.H. and Zhang, W. Y. (2012). The spoilage of airpackaged broiler meat during storage at normal and fluctuating storage temperatures. Poultry Science, 91: 208214. 